\title{
Middle-Upper Ordovician and Silurian stratigraphy and basin development in southernmost Scandinavia
}

\author{
Niels H. Schovsbo, Arne T. Nielsen and Mikael Erlström
}

A complete log-stratigraphical breakdown of the Middle Ordovician to lower Silurian shale-dominated succession is presented for the Bornholm-Skåne-Kattegat area in southernmost Scandinavia. A wireline log zonation developed for the onshore Bornholm Palaeozoic shales is extended to include the offshore Palaeozoic shales in the adjacent Rønne Graben. A complete log zonation scheme for the Cyrtograptus shale (late Llandovery-Wenlock) and the lower part of the Colonus shale (Ludlow) is presented including correlation within the Bornholm-Skåne-Kattegat area. The Cyrtograptus shale in the Bornholm area is estimated to be $400 \mathrm{~m}$ thick and marks the shift to a rapidly subsiding foreland basin, heralding the Caledonian Orogeny.

The Lower Palaeozoic shales in Denmark and southernmost Sweden are locally very thick $(>3 \mathrm{~km})$. The great thickness is mainly due to the presence of expanded Silurian units that formed in an active foreland basin related to the Caledonian Orogeny to the south and west (Michelsen \& Nielsen 1991; Vejbæk et al. 1994, Eriksson 2012; Calner

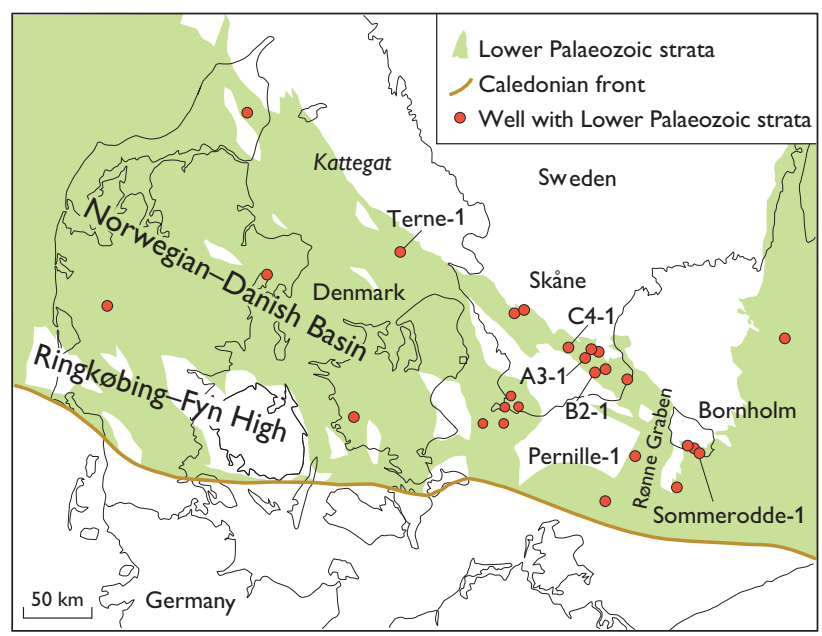

Fig. 1. Distribution of Lower Palaeozoic strata in southernmost Scandinavia with location of wells north of the Caledonian Front that reach the Lower Palaeozoic. Only wells referred to in the paper are named. Wells drilled by Shell in Skåne are Lövestad A3-1, Hedeberga B2-1 and Oderup C4-1. et al. 2013). The thick Silurian succession has only been known from a few deep exploration wells of older date with very limited wireline logging information (cf. Vejbæk et al. 1994). However, recent interest in the Scandinavian Lower Palaeozoic shales as a potential shale gas resource has led to a number of new drill holes with modern geological and geophysical logs, considerably increasing our knowledge. In a recent summary, Schovsbo et al. (2015) presented a review of the scientific work carried out over the last decade on Bornholm, based on the complete drilling and coring of the onshore Lower Palaeozoic succession. In May 2015, data acquired as part of the exploration programme for shale gas in Skåne by Royal Dutch Shell plc. (Shell) were released by the Swedish authorities, adding to our knowledge on the Lower Palaeozoic shales. These newly released data are integrated here with log data from wells on- and offshore Bornholm as well as older deep wells in western Denmark.

\section{The Oderup C4-I well}

The exploration programme carried out by Shell in Skåne included drilling of the Lövestad A3-1, Hedeberga B2-1 and Oderup C4-1 wells (Fig. 1) and acquisition of some $80 \mathrm{~km}$ of 2D seismic profiles (Calner \& Pool 2011; Pool et al. 2012). The Oderup C4-1 well drilled in central Skåne has the most complete wireline log suite and is used here as a key well for establishing a Silurian well log stratigraphy (Fig. 2). For all three wells Eriksson (2012) presented a detailed stratigraphic and lithologic evaluation as well as a wireline log-correlation between Skåne and Bornholm. Below a brief description is presented of the drilled sequence in the Oderup C4-1 well, mostly based on Calner \& Pool (2011) and Eriksson (2012).

Lower Palaeozoic strata were encountered below a Quaternary cover between 34.5 and $926.9 \mathrm{~m}$ terminal depth and the well terminated in the Lower Cambrian Hardeberga Formation. Thin Lower Cambrian Læså $(0.3 \mathrm{~m})$ and Gislöv Formations $(0.6 \mathrm{~m})$ are overlain disconformably by the Middle Cambrian - Lower Ordovician (Tremadocian) Alum Shale Formation, which is $76.3 \mathrm{~m}$ thick 


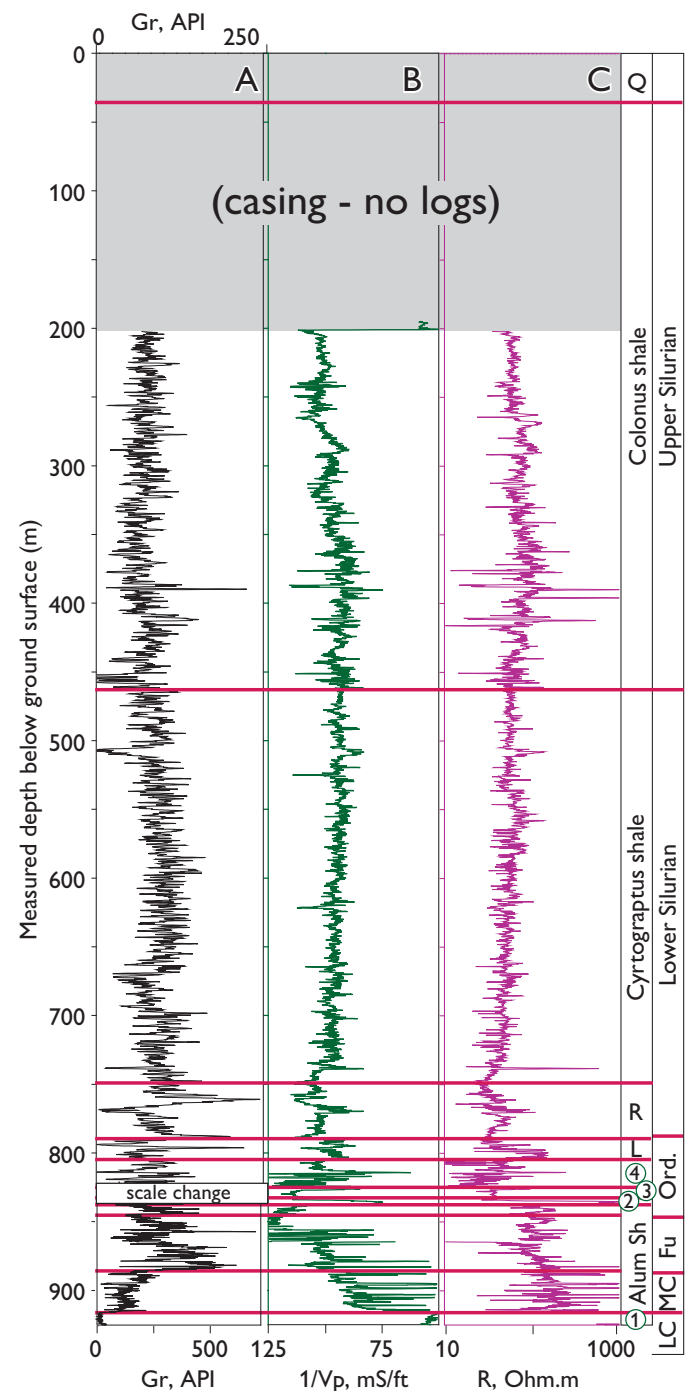

Fig. 2. A: Gamma ray curve. B: interval transit time velocity. C: formation resistivity in the Oderup C4-1 well, Skåne. Note that the definition of the Rastrites shale follows Schovsbo et al. (2015). LC: Lower Cambrian. MC: Middle Cambrian. Fu: Furongian. Ord: Ordovician. Q: Quaternary. Alum: Alum Shale Fm. L: Lindegård Fm. R: Rastrites shale. 1: Hardeberga, Læså and Gislövs fms. 2: Komstad Limestone Fm. 3: Almelund Fm. 4: Dicellograptus shale (Sularp, Mossen and Fjäcka fms).

$(836-912.3 \mathrm{~m})$. The Alum Shale Formation is in turn disconformably overlain by the lower Middle Ordovician Komstad Limestone Formation (832.5-836 m). The Komstad Limestone is in turn overlain by $44 \mathrm{~m}$ of Middle and Upper Ordovician shales (788.5-832.5 m) representing the Almelund, Sularp, Mossen, Fjäcka and Lindegård Formations (Fig. 2). The Sularp, Mossen and Fjäcka Formations are here collectively referred to as the Dicellograptus shale.

The base of the Rastrites shale (uppermost Ordovician - lower Silurian) is marked by a change to dark lithologies at $788.5 \mathrm{~m}$, which is also recorded as high gamma ray $(\mathrm{Gr})$ readings (Fig. 2). In the Oderup C4-1 final well report, the top of the Rastrites shale was identified at $733.5 \mathrm{~m}$, where a change from dark to carbonaceous light grey shale occurs. However, adopting the definitions of Schovsbo et al. (2015) the top of the Rastrites shale is here defined at a slightly deeper level corresponding to the inflection point of the formation resistivity log at $749 \mathrm{~m}$ (Fig. 2). The top of the Cyrtograptus shale is here defined at $460 \mathrm{~m}$ where a change from the dark grey Cyrtograptus shale to the light grey Colonus shale occurs. The same horizon has a distinct motif on the Gr log being marked by low readings (Fig. 2). The Colonus shale is dominated by light grey to green-grey, micaceous and slightly calcareous to arenaceous shale with frequent intercalations of grey limestone nodules (Calner $e t$ al. 2013).

\section{Wireline log-correlations}

The log-stratigraphy of Palaeozoic shales on Bornholm, originally defined by Pedersen \& Klitten (1990), has recently been redefined and extended to include the complete Rastrites shale (log zones F1-F5) and the onshore part of the Cyrtograptus shale (log zones G1-G5) by Schovsbo et al. (2015). The same log zones have been identified in the Oderup C4-1, Terne-1 and Pernille-1 wells (Fig. 3). Correlations between the Terne- 1 well and sections on Bornholm and between the Oderup C4-1 well and Bornholm have previously been presented by Michelsen \& Nielsen (1991) and Eriksson (2012), respectively, and only minor updates and corrections are made here. In the correlation panels (Fig. 3) additional log zones have been defined in the Cyrtograptus and Colonus shales (new log zones G6-G7 and $\mathrm{H} 1-\mathrm{H} 2$, respectively; see below).

\section{The new log zones of the Cyrtograptus and Colonus shales}

The Silurian G5 log zone (see Schovsbo et al. 2015) was not completely penetrated by the Sommerodde- 1 well onshore Bornholm and the top of the zone is here defined in the Pernille-1, Oderup C4-1 and Terne-1 wells as a characteristic Gr peak co-occurring with a change to slightly higher sonic $\log$ velocities (Fig. 3). According to Bjerreskov (1993) and Vejbæk et al. (1994), the base of the Pernille-1 well is within the lower Wenlock (uppermost Sheinwoodian), which is slightly older than the Cyrtograptus shale with intercalated tuff-bearing sandstone (Homerian; upper Wenlock) that is exposed at the Sommerodde beach locality onshore Bornholm (Bjerreskov \& Jørgensen 1983). This beach section immediately overlies the succession 


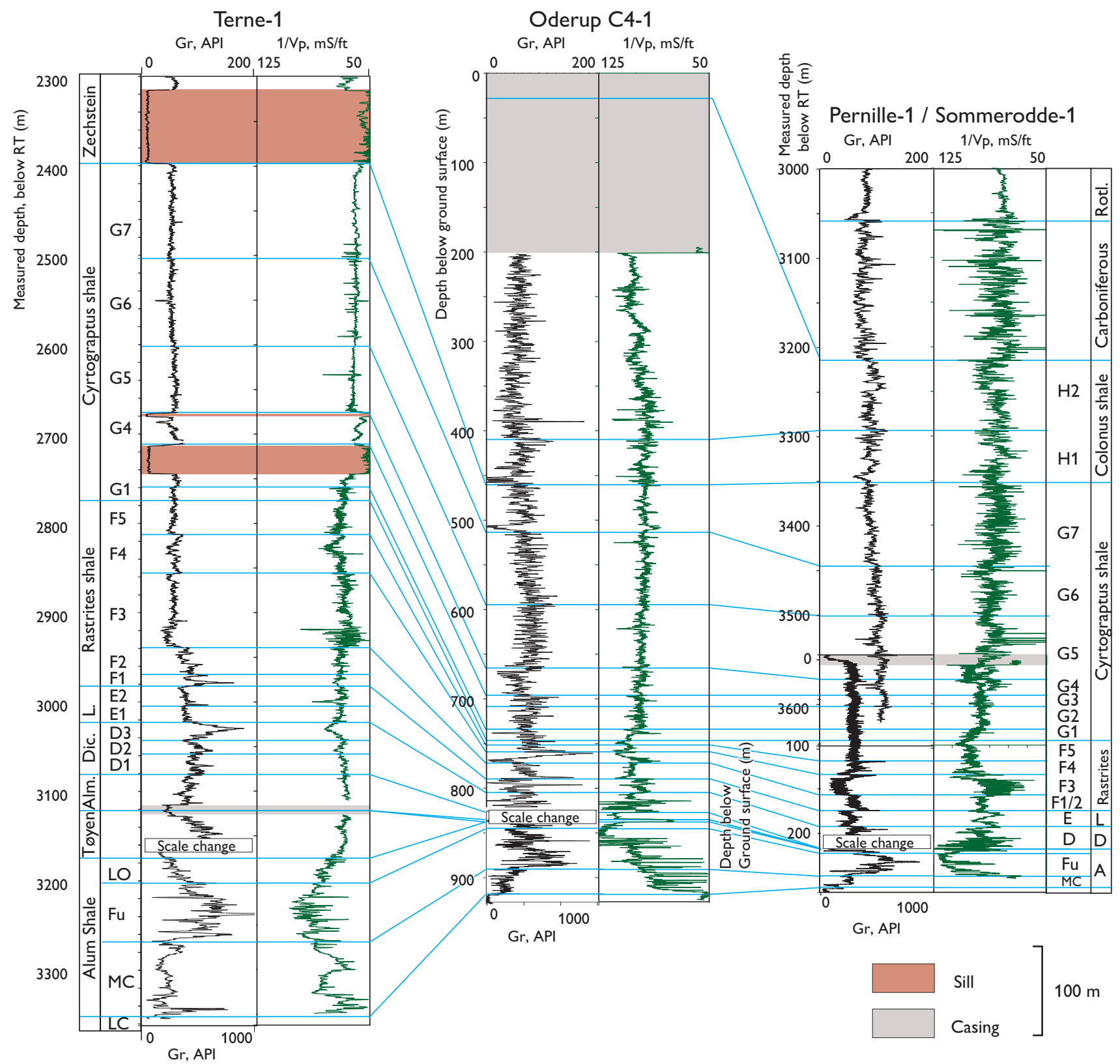

Fig. 3. Well log correlation panel between the Terne-1, Oderup C4-1, Pernille-1 and Sommerodde-1 wells (for location, see Fig. 1). The lower log zonation (D1-D3, F1-F5, G1-G5) is adopted from Schovsbo et al. (2015); the G5 (top)-G7 and H1-H2 log zones are new. For simplicity not all log zones are shown including those in the Alum Shale (cf. Schovsbo et al. 2015). Ras. sh: Rastrites shale. L: Lindegård Fm. D: Dicellograptus shale. Alm: Almelund Shale. Rotl: Rotliegendes. RT: Rotary table.

penetrated by the nearby Sommerodde- 1 well. It is inferred that the tuff-bearing sandstone interval exposed at Sommerodde is seen in the log pattern in the Pernille-1 well as zones with low $\mathrm{Gr}$ response and high sonic velocities reflecting cemented sandstone beds (Fig. 3). The G6 log zone is characterised by generally upward-decreasing $\mathrm{Gr}$ values and increasing sonic velocities. The top of the zone is defined in the wells by a slight drop in Gr activity. In the Oderup C4-1 well the top occurs just below a distinct low
Gr and high sonic velocity bed (Fig. 3). The Gr log continues to show a gradual decrease throughout log zone G7. The top of the zone is defined at an increase in Gr values and a general change to more fluctuating log signatures as seen in the Oderup C4-1 well.

The $\mathrm{H} 1 \log$ zone is distinguished by an increase in $\mathrm{Gr}$ values in comparison with the G7 zone. The top is placed at a narrow and significant $\mathrm{Gr}$ peak with low sonic velocities that could represent bentonite beds. The $\mathrm{H} 2$ log zone 
is characterised by a variable log pattern that reflects the more variable lithologies in this unit.

\section{The transition from passive margin to foreland basin}

The transition from passive margin to a foreland basin occurred in the early Silurian (Vejbæk et al. 1994; Eriksson 2012; Calner et al. 2013). In the Kattegat area continuous sedimentation took place throughout this interval whereas Bornholm and Skåne were characterised by temporary local uplifts and condensations (Fig. 3). During most of the Early, Mid and early Late Ordovician, Bornholm was uplifted and no sedimentation occurred apart from the bioclastic early Middle Ordovician Komstad Limestone Fm, whereas Skåne, as exemplified by the Oderup C4-1 well, shows variable degrees of condensation and uplift during the late Early Ordovician to early Silurian. From the onset of deposition of the Cyrtograptus shale, the difference in sedimentation between the areas converges (Fig. 3). This shift was also noted by Eriksson (2012) and Calner et al. (2013) and is interpreted to reflect the development of a rapidly subsiding foreland basin. The foregoing uplifts thus heralded the later subsidence and are seen as isostatic adjustments of the margins of Baltica, perhaps including a foreland bulge passage. The uplift first affected Bornholm and later Skåne but apparently did not influence the Kattegat area where continuous subsidence occurred throughout the Ordovician and Silurian.

\section{Conclusions}

A complete log-stratigraphical breakdown of the Middle Ordovician to lower Silurian shale-dominated succession is presented for the Bornholm-Skåne-Kattegat area in southernmost Scandinavia. The Cyrtograptus shale (of late Llandovery-Wenlock age) is subdivided into seven log zones and is estimated to be approximately $400 \mathrm{~m}$ thick in the Bornholm area based on the Sommerodde-Pernille composite section (Fig. 3). The lower part of the overlying Colonus shale (Ludlow) is divided into two log zones; the total thickness of this shale is unknown. Variable degrees of condensation and uplift occurred in Skåne and on Bornholm during the late Early Ordovician to early Silurian.
From the onset of the Cyrtograptus shale deposition, the difference in sedimentation between the areas converges and this shift is interpreted to reflect the development of a rapidly subsiding foreland basin.

\section{Acknowledgements}

GeoCenter Denmark is thanked for financial support to the project 'Silurian stratigraphy and Basin development' awarded to NHS and ATN. Comments from reviewers Svend Stouge and Mikael Calner helped improving the final version of the manuscript.

\section{References}

Bjerreskov, M. 1993: Pernille-1 well graptolite fauna. GEUS report file 10567. Reported as part of a EFP-89 project. DGU kunderapport $1-5$.

Bjerreskov, M. \& Jørgensen, K.A. 1983: Late Wenlock graptolite-bearing tuffaceous sandstone from Bornholm, Denmark. Bulletin of the Geological Society of Denmark 31, 129-149.

Calner, M. \& Pool, W. 2011: The first deep wells in the Lower Palaeozoic Colonus Shale Trough, Sorgenfrei-Tornquist tectonic zone, southern Sweden. GFF 133, 58-59. Stockholm: Geological Society of Sweden.

Calner, M., Erlström, M., Lehnert, O. \& Ahlberg, P. 2013: Lower Palaeozoic geology of southern Sweden. In: Calner, M. et al. (eds): The Lower Palaeozoic of southern Sweden and the Oslo Region, Norway. Field Guide for the 3rd Annual Meeting of the IGCP project 591. SGU Rapporter och meddelanden 133, 6-9.

Eriksson, M. 2012: Stratigraphy, facies and depositional history of the Colonus Shale Trough, Skåne, southern Sweden. Dissertations in Geology at Lund University 310, $37 \mathrm{pp}$.

Michelsen, O. \& Nielsen, L.H. 1991: Well records on the Phanerozoic stratigraphy in the Fennoscandian Border Zone, Denmark: Hans-1, Sæby-1, and Terne-1 wells. Danmarks Geologiske Undersøgelse Serie A 29, $37 \mathrm{pp}$.

Pedersen, G.K. \& Klitten, K. 1990: Anvendelse af gamma-logs ved korrelation af marine skifre i vandforsyningsboringer på Bornholm. Dansk Geologisk Forening Årsskrift 1987-89, 21-35.

Pool, W., Geluk, M., Abels, J. \& Tiley, G. 2012: Assessment of an unusual European shale gas play: the Cambro-Ordovician Alum Shale, southern Sweden: Proceedings of the Society of Petroleum Engineers/European Association of Geoscientists and Engineers Unconventional Resources Conference, Vienna, Austria, March 20-22, 152339

Schovsbo, N.H., Nielsen A.T. \& Klitten, K. 2015: The Lower Palaeozoic now fully cored and logged on Bornholm. Geological Survey of Denmark and Greenland Bulletin 33, 9-12.

Vejbæk, O.V., Stouge, S. \& Poulsen, K.D. 1994: Palaeozoic tectonic and sedimentary evolution and hydrocarbon prospectivity in the Bornholm area. Danmarks Geologiske Undersøgelser Serie A 34, 21 pp.

\footnotetext{
Authors' addresses

N.H.S., Geological Survey of Denmark and Greenland (GEUS), Øster Voldgade 10, DK-1350 Copenhagen K, Denmark. E-mail: nsc@geus.dk A.T.N., Dept. of Geosciences and Natural Resource Management, University of Copenhagen, Øster Voldgade 10, DK-1350 Copenhagen K, Denmark. M.E., Geological Survey of Sweden (SGU), Kiliansgatan 10, SE-223 50 Lund, Sweden.
} 